\title{
Assimilation of selenium in the marine copepod Acartia tonsa studied with a radiotracer ratio method* $^{*}$
}

\author{
Nicholas S. Fisher, John R. Reinfelder \\ Marine Sciences Research Center, State University of New York, Stony Brook, New York 11794-5000, USA
}

\begin{abstract}
Assimilation of selenium in the marine copepod Acartia tonsa, feeding on the diatom Thalassiosira pseudonana, was studied using a new dual-label radiotracer ratio method. Copepods were fed diatoms labeled with the gamma-emitting isotopes ${ }^{75} \mathrm{Se}$ and ${ }^{241} \mathrm{Am}$. The diatoms had concentrated selenite ${ }^{75} \mathrm{Se} 1.1 \times 10^{5}$ times and ${ }^{241} \mathrm{Am} 2.9 \times 10^{5}$ times out of seawater. Mass balance calculations indicated that only about $1 \%$ of the ingested ${ }^{241} \mathrm{Am}$ was retained in the copepods after gut evacuation, suggesting this isotope as an excellent tracer of bulk ingested material. The assimilation efficiency of the ingested ${ }^{75} \mathrm{Se}$ was determined by relating its activity to that of ${ }^{241} \mathrm{Am}$ in the food and fecal pellets of the copepod. The ${ }^{75}$ Se concentration in the feces was consistently lower than that in the food by over an order of magnitude. The assimilation efficiency of selenium in $A$. tonsa was found to be $97.1 \pm 1.5 \%$ over a series of experiments, and remained constant over feeding periods ranging from 6 to $49.5 \mathrm{~h}$. Mass balance calculations of selenium assimilation efficiency gave comparable values to those generated with the ratio method. The high assimilation efficiency of selenium in planktonic animals may account for its relatively long residence time in surface waters. The application of a dual gamma-emitting radiotracer ratio method for determining assimilation efficiencies of ingested elements could be readily extended to many other elements and animals
\end{abstract}

\section{INTRODUCTION}

Marine zooplankton, by packaging ingested material into rapidly sinking fecal pellets, can facilitate the vertical transport of elements out of surface waters (Angel 1984, Fowler \& Knauer 1986, Small et al. 1987). Elements which do not enter the organic cycle, show little assimilation in animals, and concentrate in zooplankton feces have shorter residence times in surface waters than elements that are appreciably assimilated by planktonic consumers and recycled in organic compounds (Whitfield \& Turner 1987). Therefore, in the context of understanding the biogeochemical cycling of elements in marine systems, it is important to measure the assimilation efficiency of elements by the zooplankton. Moreover, the assimilation efficiency of an element can dictate the extent to which it is biologically utilizable or toxic in an animal.

Assimilation efficiencies can be very difficult to measure and estimates for specific elements within a

\footnotetext{
- Contribution No. 767 from the Marine Sciences Research Center
}

species have typically been highly variable. Traditional mass balance methods in which ingested and excreted material are quantitatively compared include the difficult task of trying to collect all of the fecal material, which is typically small and subject to mechanical destruction. Further, difficulties can arise because fecal pellets can also lose some material into the dissolved phase (Fisher et al. 1983b). Mass balance methods also do not take into account the presence of gut-derived secretions that can contribute to fecal mass, a problem that can be avoided by the use of radiotracers (Calow \& Fletcher 1972).

To address some of these difficulties, ratio methods have been developed in which the amount of an assimilable element is compared to the amount of a non-assimilated 'indicator' component in the food and fecal material, the assimilated element being depleted in the feces relative to the inert component (Conover 1966, Calow \& Fletcher 1972, Bricelj et al. 1984, Tande \& Slagstad 1985). By combining radiotracers with the ratio method, it is only necessary to measure the ratio of the assimilated element's radiotracer to that of the inert component in samples of the food and the feces. Quan- 
titative recovery of all excretory products is not necessary. The success of this method depends largely on the behavior of the inert 'indicator' element in the gut of the animal under investigation. Any appreciable or variable assimilation of this bulk tracer would require extensive 'corrections' to the calculated assimilation efficiencies. Moreover, the gut residence time of this unassimilated tracer should not be appreciably longer than that of the assimilated element(s). The radiotracer methods developed thus far have utilized beta-emitting radioisotopes (e.g. ${ }^{14} \mathrm{C}$ ), sometimes in conjunction with a gamma-emitting isotope $\left({ }^{51} \mathrm{Cr}\right)$. Thus, assimilation efficiency, according to the method of Calow \& Fletcher (1972), is calculated to equal:

$$
\frac{{ }^{14} \mathrm{C} /{ }^{51} \mathrm{Cr} \text { in the food }-{ }^{14} \mathrm{C} /{ }^{51} \mathrm{Cr} \text { in the feces }}{{ }^{14} \mathrm{C} /{ }^{51} \mathrm{Cr} \text { in the food }}
$$

Problems arise, however, in counting beta and gammaemitting radioisotopes in the same sample: 2 different counters are typically needed, and interference by ${ }^{51} \mathrm{Cr}$ in counting ${ }^{14} \mathrm{C}$ can be substantial.

We have therefore developed a double radiotracer ratio method for determining assimilation efficiencies of ingested elements in animals using only gammaemitting radioisotopes. In this paper we present the results of a study in which ${ }^{75} \mathrm{Se}$ and ${ }^{241} \mathrm{Am}$ were used to study the assimilation efficiency of selenium by the pelagic copepod Acartia tonsa using the ratio technique. Americium, a highly particle-reactive, nonessential element, shows essentially no assimilation in marine zooplankton and was therefore considered as an excellent potential tracer of bulk ingested material (Fisher et al. 1983a, b).

\section{MATERIALS AND METHODS}

The calanoid copepod Acartia tonsa was collected from Stony Brook Harbor, Long Island, USA in summer. Copepods were maintained in the laboratory in $35 \mathrm{ppt}$ glass-fiber-filtered seawater at $18{ }^{\circ} \mathrm{C}$ and were fed the prymnesiophyte Isochrysis galbana and the diatom Thalassiosira pseudonana prior to experiments. Feeding experiments used only $T$. pseudonana (clone $3 \mathrm{H}$ ). Cultures of $T$. pseudonana were axenically maintained in sterile filtered ( $0.2 \mu \mathrm{m}$ Nuclepore) nearshore surface seawater (collected $8 \mathrm{~km}$ off Shinnecock, Long Island) enriched with $\mathrm{f} / 2$ nutrients (Guillard \& Ryther 1962). Experimental inocula were obtained by resuspending cells off a sterile $1 \mu \mathrm{m}$ Nuclepore filter (washed with sterile filtered seawater) into sterile filtered seawater for radioisotope uptake. Initial cell densities were set at $10^{4}$ cells $\mathrm{ml}^{-1}$. Nutrient enrichment for the isotope accumulation media included f/2 N, P and vitamins, f/50 Mo, Mn, Co, Fe and $\mathrm{Si}$, but no added $\mathrm{Cu}, \mathrm{Zn}$ or EDTA. In replicate experiments, diatom cultures held at $18^{\circ} \mathrm{C}$ were illuminated with cool white fluorescent lamps (L : D $14: 10 \mathrm{~h}$ cyclic illumination of $210 \mu \mathrm{Ein} \mathrm{m}^{-2}$ $\mathrm{s}^{-1}$ ) and exposed to a range of ${ }^{75} \mathrm{Se}$ and ${ }^{241}$ Am concentrations. Thus, algal cells were exposed to 18.5 to 37 $\mathrm{kBq} \mathrm{I}^{-1}(0.6$ to $1.2 \mathrm{nM}){ }^{241} \mathrm{Am}$ and 37.0 to $660 \mathrm{kBq} \mathrm{l}^{-1}$ $(0.136$ to $2.42 \mathrm{nM}){ }^{75} \mathrm{Se}$ for $3 \mathrm{~d}$. The ${ }^{241} \mathrm{Am}\left(\mathrm{t}_{1 / 2}=433 \mathrm{yr}\right)$ was taken from a stock solution in $3 \mathrm{~N} \mathrm{HNO}_{3}$ while the ${ }^{75} \mathrm{Se}\left(\mathrm{t}_{1 / 2}=120 \mathrm{~d}\right)$ was from a stock in $0.5 \mathrm{~N} \mathrm{HCl}$ as selenious acid.

Because selenium is a group VIA element and has many physical and chemical attributes like those of sulfur (Bagnall 1973), it can behave as a sulfur analog in algae (Shrift 1954, Wrench 1978). A comparison of the subcellular distribution of these 2 elements in Thalassiosira pseudonana cells was therefore made. Cells were inoculated $\left(10^{4} \mathrm{ml}^{-1}\right)$ into $250 \mathrm{ml}$ of sterile filtered seawater enriched with $\mathrm{f} / 2$ nutrients and $3700 \mathrm{kBq}$ of ${ }^{35} \mathrm{~S} \mathrm{Na}_{2} \mathrm{SO}_{4}$, a beta-emitting radiotracer. Radiolabeled algal cells were fractionated by differential centrifugation (Sorvall refrigerated ultracentrifuge) after osmotic disruption, following the protocol of Fisher et al. (1983c). The radioactivity and protein content of each of the 4 fractions (collected at $754 \times g$, $5 \mathrm{~min} ; 2000 \times g, 15 \mathrm{~min} ; 10000 \times g, 15 \mathrm{~min}$; supernatant) were determined. The enhanced sensitivity BCA method was used to measure protein concentrations (Smith et al. 1985).

Four experiments were conducted in which algal cells, after accumulation of radioisotope, were collected on $1 \mathrm{\mu m}$ Nuclepore filters and resuspended into 100 to $250 \mathrm{ml}$ unlabeled, unenriched, sterile filtered seawater to give cell densities in the experimental feeding suspensions ranging from 1.33 to $2.10 \times 10^{5}$ cells $\mathrm{ml}^{-1}$ (representing 2.9 to $4.7 \mathrm{mg}$ dry wt or 8.1 to $\left.12.8 \times 10^{9} \mu \mathrm{m}^{3} 1^{-1}\right)$. The experimental conditions of each experiment are shown in Table 1. Copepods were added to these cell suspensions to give average densities of about 20 individuals per $200 \mathrm{ml}$ (Table 1 ). The copepods fed on labeled diatoms for $6 \mathrm{~h}$ in the dark at $18^{\circ} \mathrm{C}$, after which they were allowed to empty their guts for at least $12 \mathrm{~h}$ following transfer to sterile filtered seawater containing unlabeled Thalassiosira pseudonana $\left(1 \times 10^{5}\right.$ cells $\left.\mathrm{ml}^{-1}\right)$. Since the gut residence time of both ${ }^{75} \mathrm{Se}$ and ${ }^{241} \mathrm{Am}$ in ingested food is $<30 \mathrm{~min}$, the 'cold' feeding period should have been ample to purge all undigested radioactivity from the copepods.

Feces and eggs were collected at the end of the $6 \mathrm{~h}$ radioactive feedings using a $20 \mu \mathrm{m}$ Nitex mesh and rinsed with $10 \mathrm{ml}$ sterile filtered seawater to eliminate any trapped pools of radioisotope. Fecal pellets were separated from eggs and other unidentifiable debris caught on the Nitex mesh with a drawn-out Pasteur 
Table 1. Experimental conditions in the 4 experiments

\begin{tabular}{|c|c|c|c|c|c|c|c|}
\hline \multirow[t]{2}{*}{ Expt } & \multicolumn{2}{|c|}{$\begin{array}{c}\text { Isotope activity } \\
\text { and concentrations } \\
\text { for diatom uptake } \\
\mathrm{kBq} \mathrm{l}^{-1}(\mathrm{nM})\end{array}$} & \multirow[t]{2}{*}{$\begin{array}{l}\text { Cell density } \\
\text { during feeding } \\
\text { cells } \mathrm{ml}^{-1} \times 10^{5} \\
\text { ( } \mathrm{g} \text { gry wt } \mathrm{ml}^{-1} \text { ) }\end{array}$} & \multicolumn{2}{|c|}{$\begin{array}{c}\text { Isotope activity } \\
\text { per cell during } \\
\text { feeding } \\
\mu \mathrm{Bq} \text { cell }\end{array}$} & \multirow[t]{2}{*}{$\begin{array}{l}\text { Feeding } \\
\text { volume } \\
\text { (ml) }\end{array}$} & \multirow[t]{2}{*}{$\begin{array}{l}\text { Copepods } \\
\text { per flask }\end{array}$} \\
\hline & ${ }^{75} \mathrm{Se}$ & ${ }^{241} \mathrm{Am}$ & & ${ }^{75} \mathrm{Se}$ & ${ }^{241} \mathrm{Am}$ & & \\
\hline 1 & $\begin{array}{c}37 \\
(0.136)\end{array}$ & $\begin{array}{c}37 \\
(1.2)\end{array}$ & $\begin{array}{l}1.37 \\
(3.1)\end{array}$ & 63.6 & 32.5 & 250 & 23 \\
\hline 2 & $\begin{array}{c}37 \\
(0.136)\end{array}$ & $\begin{array}{c}37 \\
(1.2)\end{array}$ & $\begin{array}{c}2.1 \\
(4.7)\end{array}$ & 61.3 & 26.6 & 100 & 10 \\
\hline 3 & $\begin{array}{c}185 \\
(0.679)\end{array}$ & $\begin{array}{l}18.5 \\
(0.6)\end{array}$ & $\begin{array}{l}1.37 \\
(3.1)\end{array}$ & 283.5 & 32.4 & 250 & 21 \\
\hline 4 & $\begin{array}{c}660 \\
(2.42)\end{array}$ & $\begin{array}{l}18.5 \\
(0.6)\end{array}$ & $\begin{array}{l}1.33 \\
(3.0)\end{array}$ & 137.5 & 14.6 & 200 & 25 \\
\hline
\end{tabular}

pipette and were placed on a 1 m Nuclepore filter; they were rinsed twice with $5 \mathrm{ml}$ filtered seawater to remove any remaining unbound isotope. Collected fecal pellets and eggs were then counted for their radioactivity. Eggs were not collected in Expt 1.

The assimilation efficiency of selenium was determined by 2 methods. One method involved the use of the ratios of ${ }^{75} \mathrm{Se}:{ }^{241} \mathrm{Am}$ activity in the food and fecal pellets as described by the equation:

Assim. eff. $=\frac{{ }^{75} \mathrm{Se}^{241} \mathrm{Am} \text { (food) }-{ }^{75} \mathrm{Se}^{241} \mathrm{Am} \text { (feces) }}{{ }^{75} \mathrm{Se} /{ }^{241} \mathrm{Am}(\text { food) }}$

The second approach used mass balance by comparing the amount of ingested ${ }^{75} \mathrm{Se}$ (and ${ }^{241} \mathrm{Am}$ ) to that retained by the copepods after gut evacuation. The amount of ingested radioisotope was calculated as the sum of the isotope in fecal pellets and copepods after gut evacuation.

Loss of ${ }^{75} \mathrm{Se}$ and ${ }^{241} \mathrm{Am}$ from Thalassiosira pseudonana and from the fecal pellets of Acartia tonsa was examined over an $8 \mathrm{~d}$ period. Labeled algal cells were transferred to unlabeled sterile filtered seawater to which no copepods were added; cell densities were identical to those in the feeding suspensions with copepods. Partitioning of ${ }^{75} \mathrm{Se}$ and ${ }^{241} \mathrm{Am}$ between the 'dissolved' and particulate phases was determined using established techniques (Fisher et al. 1983a).

${ }^{75} \mathrm{Se}$ - and ${ }^{241} \mathrm{Am}$-labeled fecal pellets from Acartia tonsa collected at the end of a 6 h feeding period were transferred to $9 \mathrm{ml}$ of isotope-free glass fiber (GFC) filtered seawater. The upper $8.5 \mathrm{ml}$ of seawater were periodically removed by careful pipetting without disturbing the settled fecal pellets which were assayed for radioactivity. After counting, $8.5 \mathrm{ml}$ of fresh unlabeled GFC filtered seawater was then added to the fecal pellets.

The radioactivity of ${ }^{75} \mathrm{Se}$ and ${ }^{241} \mathrm{Am}$-containing samples was measured using a Pharmacia-Wallac LKB
CompuGamma with a well-type NaI(Tl) crystal. The ${ }^{75} \mathrm{Se}$ and ${ }^{241} \mathrm{Am}$ contents of samples were determined by counting the gamma emissions at 264 and $60 \mathrm{keV}$, respectively. ${ }^{35} \mathrm{~S}$-containing samples were placed in glass vials with $10 \mathrm{ml}$ Aquasol and counted with an LKB Rack Beta liquid scintillation counter. Quenching was corrected using the external standards ratio method. Counting times for all samples were adjusted so that propagated counting errors were $<5 \%$.

\section{RESULTS}

A typical uptake graph for selenite ${ }^{75} \mathrm{Se}$ and ${ }^{241} \mathrm{Am}$ in Thalassiosira pseudonana is given in Fig. 1. Accumulation of ${ }^{75}$ Se levels off with cessation of cell growth, while ${ }^{241}$ Am uptake continues throughout the $3 \mathrm{~d}$ uptake period, with nearly $75 \%$ of the total added radioisotope becoming associated with the particulate

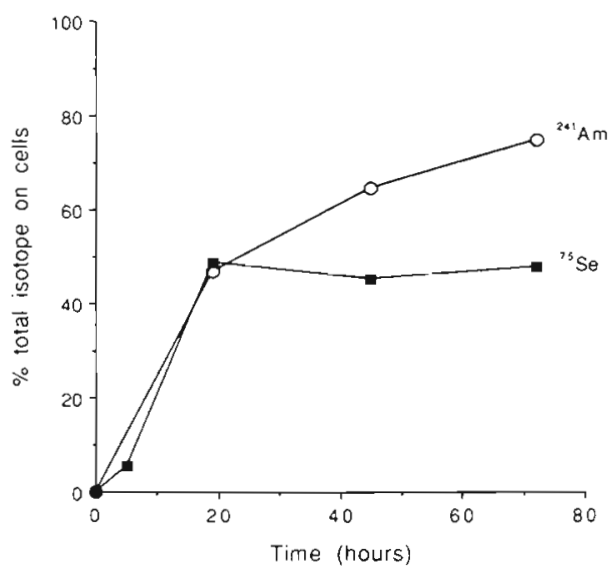

Fig. 1. Thalassiosira pseudonana. Uptake of ${ }^{75} \mathrm{Se}(\boldsymbol{\bullet})$ and ${ }^{241} \mathrm{Am}$ (o) by diatoms over time. Values shown are fractions of total isotope in the water column associated with cells at each sample time 
(i.e. cell) phase in the case shown here. At the final sample time, volume/volume concentration factors (VCF) were determined for each element in the diatoms (Fisher et al. 1983a):

$$
\text { VCF }=\frac{\text { metal } \mu \mathrm{m}^{-3} \text { cell }}{\text { metal } \mu \mathrm{m}^{-3} \text { dissolved }}
$$

Selenium attained a VCF of $1.1 \times 10^{5}$; americium's VCF was $2.9 \times 10^{5}$. Unlike sulfur, selenium did not correlate well with the protein content of all the subcellular fractions of the diatom cells (Fig. 2). The supernatant fraction, which had $40 \%$ of the total cellular ${ }^{35} \mathrm{~S}$ and $37 \%$ of the cell protein, was enriched in ${ }^{75} \mathrm{Se}$, containing $84 \%$ of the cellular contents.

In contrast to the algae, copepods feeding on labeled diatoms for up to $50 \mathrm{~h}$ showed a fairly steady increase

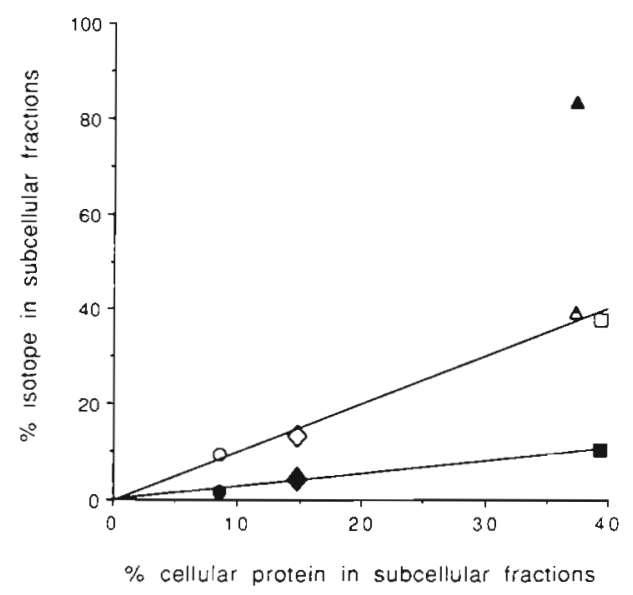

Fig. 2. Thalassiosira pseudonana. Comparison of the percent of total cellular ${ }^{35} \mathrm{~S}$ and ${ }^{75} \mathrm{Se}$ with the percent of total cellular protein in each subcellular fraction. $(\square,-)$ Pellet $1,754 \times g_{i}(0$, -) pellet 2,2000× $g_{i}(0, \bullet)$ pellet $3,10000 \times g_{i}(\Delta, \Delta)$ supernatant. Linear fit of ${ }^{35} \mathrm{~S}$ vs protein in all fractions: open symbols: $y=1.013 x-0.334(r=0.993, p<0.001)$. Linear fit of

${ }^{75} \mathrm{Se}$ vs protein in all fractions other than supernatant: closed symbols: $y=0.265 x-0.142(r=0.994, p<0.001)$ in ${ }^{75} \mathrm{Se}$, while their body burden of ${ }^{241} \mathrm{Am}$ remained essentially constant (Fig. 3).

The ${ }^{75} \mathrm{Se}$ and ${ }^{241} \mathrm{Am}$ levels in the diatoms fed to the copepods and in the zooplankton fecal pellets produced during the $6 \mathrm{~h}$ feeding are presented in Table 2. The ${ }^{241}$ Am was reduced by up to 7 -fold in the fecal pellets relative to the food (expressed on a $\mathrm{Bq} \mu \mathrm{g}^{-1}$ dry wt basis), although this varied among the experiments, while the ${ }^{75} \mathrm{Se}$ concentration in the fecal pellets was always reduced by about 2 orders of magnitude relative to concentrations in the food (Table 2). Mean ${ }^{75} \mathrm{Se}:{ }^{241} \mathrm{Am}$ ratios in the food and fecal pellets, together with the calculated selenium assimilation efficiencies, are also shown for the 4 feeding experiments in Table 2. The calculated assimilation efficiencies $-97.1 \pm$ $1.5 \%$ - were remarkably high and showed remarkable constancy for the 4 experiments, each of which was conducted with different batches of algal cells and copepods collected months apart. This constancy was maintained regardless of the inter-experimental variation (up to 4.8-fold) in the Se: Am ratios in the algal food (Table 2). Analysis of the eggs produced by female

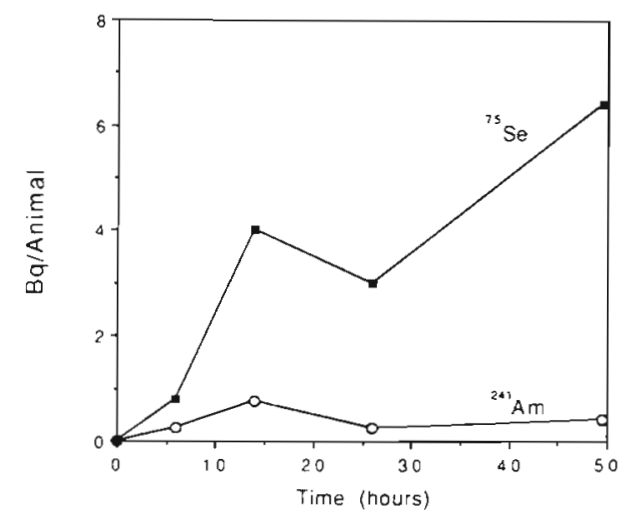

Fig. 3. Acartia tonsa. Accumulation of ${ }^{75} \mathrm{Se}(\boldsymbol{m})$ and ${ }^{241} \mathrm{Am}(0)$ activity (Bq) per individual copepod fed double-labeled diatoms for $49.5 \mathrm{~h}$

Table 2. Acartia tonsa. Radioactivity of ingested and excreted material and assimilation efficiencies of Se, based on the ratio method

\begin{tabular}{|c|c|c|c|c|c|c|c|}
\hline \multirow[t]{2}{*}{ Expt } & \multicolumn{3}{|c|}{$\begin{array}{c}\text { Radioactivity } \\
\text { in food } \\
\left(\mathrm{Bq} \mu \mathrm{g}^{-1} \mathrm{dry} w \mathrm{t}\right)^{\mathrm{a}}\end{array}$} & \multicolumn{3}{|c|}{$\begin{array}{c}\text { Radioactivity } \\
\text { in fecal pellets } \\
\left(\mathrm{Bq} \mu \mathrm{g}^{-1} \text { dry wt }\right)^{\mathrm{b}}\end{array}$} & \multirow[t]{2}{*}{$\begin{array}{c}\text { Assimilation } \\
\text { efficiency } \\
\text { of Se }(\%)\end{array}$} \\
\hline & Se & Am & $\mathrm{Se} / \mathrm{Am}$ & $\mathrm{Se}$ & Am & $\mathrm{Se} / \mathrm{Am}$ & \\
\hline 1 & 2.99 & 1.53 & 1.954 & 0.0318 & 0.793 & 0.040 & 98.0 \\
\hline 2 & 2.74 & 1.19 & 2.303 & 0.0147 & 0.165 & 0.089 & 96.1 \\
\hline 3 & 12.65 & 1.44 & 8.785 & 0.0988 & 0.252 & 0.392 & 95.5 \\
\hline \multirow[t]{2}{*}{4} & 6.14 & 0.65 & 9.446 & 0.0780 & 0.639 & 0.122 & 98.7 \\
\hline & & & & & & \multicolumn{2}{|c|}{ Mean: $97.1 \pm 1.5$} \\
\hline
\end{tabular}


copepods indicated that from 0 to $1.5 \%$ of the ingested ${ }^{241} \mathrm{Am}$ and about $2 \%$ of the ingested ${ }^{75} \mathrm{Se}$ was deposited in the eggs. Using a mass balance approach (in which the ${ }^{241} \mathrm{Am}$ activity remaining in the copepods after gut evacuation was compared with the activity in the fecal pellets), the assimilation efficiency of ${ }^{241} \mathrm{Am}$ in Acartia tonsa was calculated to range from 0.35 to $1.36 \%$.

Within any one experiment, the Se: Am ratios in the food and fecal pellets were found to be constant throughout the $6 \mathrm{~h}$ feeding period (Fig. 4), indicating that, for the purpose of determining assimilation efficiency, samples of food and feces could be taken at any time during the feeding period and could be considered representative. A comparison of the selenium assimilation efficiencies for Acartia tonsa found by ratio calculation and by mass balance is shown in Fig. 5 . There were no significant differences observed between the 2 methods, even when radioactive feeding was extended for up to $49.5 \mathrm{~h}$. Moreover, the assimilation efficiency of ${ }^{75} \mathrm{Se}$ stayed essentially constant over this period.

The loss of ${ }^{75} \mathrm{Se}$ and ${ }^{241} \mathrm{Am}$ from the diatoms in the absence of copepods during the $6 \mathrm{~h}$ feeding was 25 and $20 \%$, respectively (Fig. 6). Loss of these 2 isotopes from the diatoms into the water was describable by a 2 compartment model, in which there was an initial sharp loss from the rapidly exchanging pool within the first hour, followed by a much reduced loss rate for ${ }^{75} \mathrm{Se}$ $\left(\mathrm{t}_{1 / 2}=126 \mathrm{~h}\right)$ and no detectable loss of ${ }^{241} \mathrm{Am}$. Since the diatoms lost some isotope into the 'dissolved' phase during the $6 \mathrm{~h}$ feeding period, dissolved ${ }^{75} \mathrm{Se}$ and ${ }^{241} \mathrm{Am}$ in the feeding suspension could have contributed to the accumulation of these tracers by the copepods. The extent to which this released isotope could have associated with the copepods was tested by putting unlabeled Acartia tonsa individuals for $6 \mathrm{~h}$ into sea-

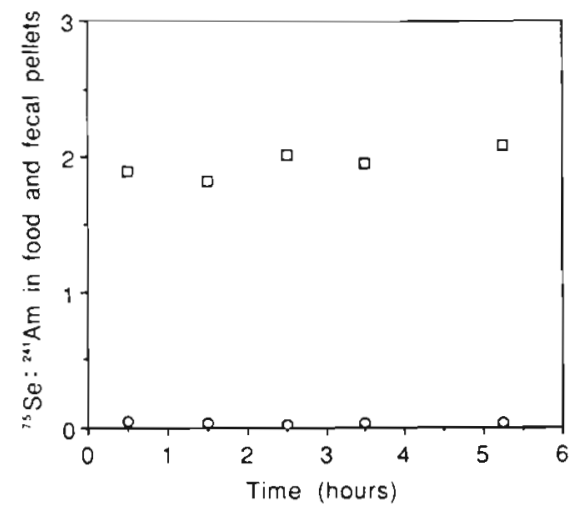

Fig. 4. Ratio of ${ }^{75} \mathrm{Se}:{ }^{241} \mathrm{Am}$ activity in labeled Thalassiosira pseudonana ( $\square$ ) and Acartia tonsa fecal pellets (o) during $6 \mathrm{~h}$ feeding period. Copepods were returned to their feeding suspension after removal of feces and diatom samples at each sampling time water in which double-labeled Thalassiosira pseudonana cells had been allowed to depurate for $6 \mathrm{~h}$ and then were removed by filtration. The results of this experiment indicated that the maximum contribution from the dissolved phase to the copepod body burden of $\mathrm{Am}$ and Se was 3.9 and $5.6 \%$, respectively.

The release of ${ }^{75} \mathrm{Se}$ and ${ }^{241} \mathrm{Am}$ from labeled fecal pellets into the dissolved phase was also describable by a 2-compartment model. By $12 \mathrm{~h}$, the rapidly exchanging pools were noted by the loss of 53 and $23 \%$ of ${ }^{75} \mathrm{Se}$

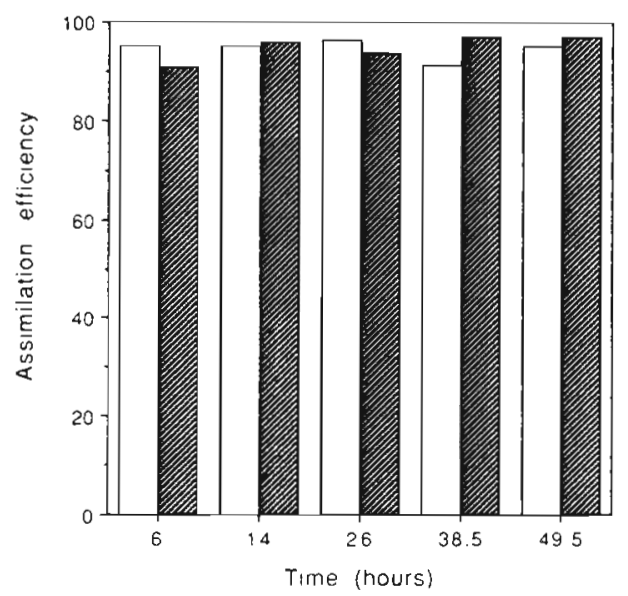

Fig. 5. Acartia tonsa. Comparison of selenium assimilation efficiencies in copepods feeding on radiolabeled Thalassiosira pseudonana cells for up to $49.5 \mathrm{~h}$, calculated using the mass balance approach (hatched bars) and the ratio method (open bars)
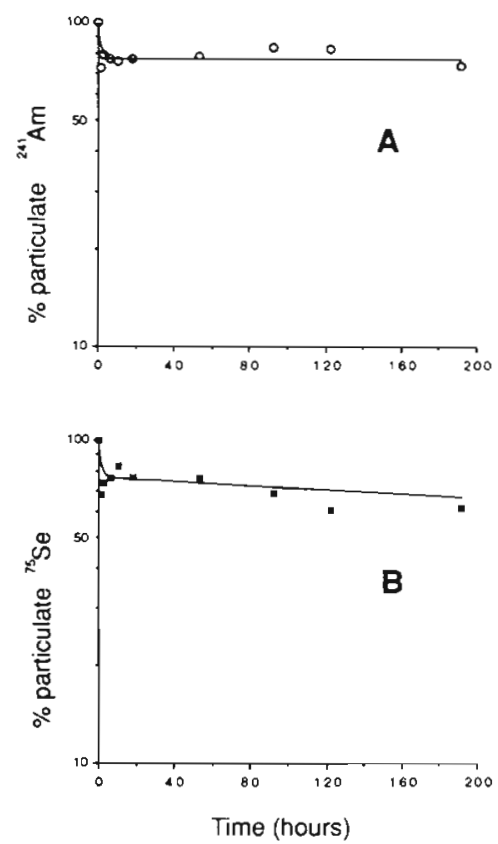

Fig. 6. Thalassiosira pseudonana. Retention of (A) ${ }^{241} \mathrm{Am}$ and (B) ${ }^{75} \mathrm{Se}$ by double-labeled cells resuspended in unlabeled sterile-filtered seawater 
and ${ }^{241}$ Am respectively from the feces (Fig. 7). After $12 \mathrm{~h}$, the fecal pellets exhibited a more gradual net loss of both radiotracers, indicating the presence of more slowly exchanging pools, with retention half times of $8.5 \mathrm{~d}$ and $20 \mathrm{~d}$ for ${ }^{75} \mathrm{Se}$ and ${ }^{241} \mathrm{Am}$, respectively (Fig. 7).

\section{DISCUSSION}

The high concentration factor observed for selenite selenium ranks this element among the most concentrated elements in marine phytoplankton (Fisher 1986). Most of the other elements which have comparably high concentration factors (e.g. the actinides) are accumulated from seawater passively by phytoplankton and are associated principally with cell surfaces (Fisher 1986). The selenite additions to which the cells were exposed in our experiments, from 0.136 to $2.42 \mathrm{nM}$, were at or above the minimum amount required to support Thalassiosira pseudonana growth (Price et al. 1987) and natural concentrations of total selenium (ca $1 \mathrm{nM}$ ) in surface coastal waters (Measures \& Burton 1980, Cutter 1982).

Selenium has been thought to behave as a sulfur analog in algae and higher plants, being metabolized into seleno-amino acids (Shrift 1954, Wrench 1978, Brown \& Shrift 1982). Our fractionation results with Thalassiosira pseudonana (Fig. 2), however, show that selenium, unlike sulfur, does not correlate with protein in all the subcellular fractions due to a large pool of selenium in the supernatant or soluble cellular fraction. Large pools of soluble selenium have also been identified

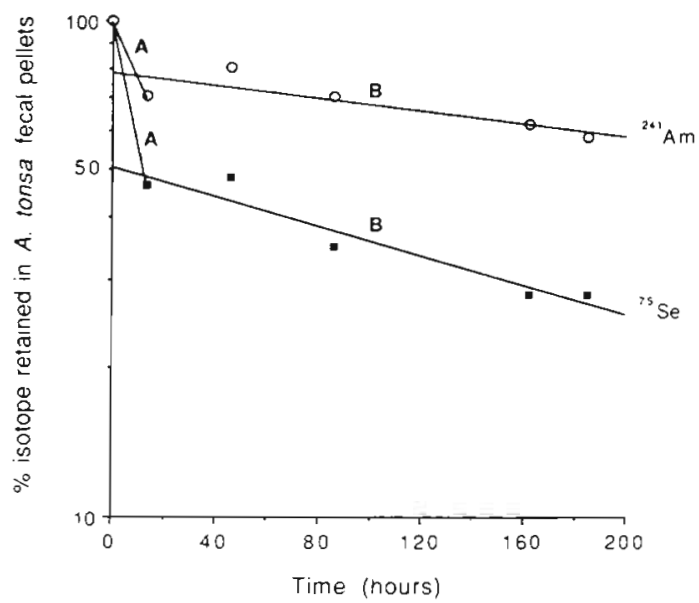

Fig. 7. Retention of ${ }^{75} \mathrm{Se}(\mathbf{})$ and ${ }^{241} \mathrm{Am}(\mathrm{c})$ in Acartia tonsa fecal pellets resuspended into unlabeled GFC filtered seawater Retention half-times $\left(t_{r_{1 / 2}}\right)$ for the rapidly exchanging pools (A) of ${ }^{75} \mathrm{Se}$ and ${ }^{241} \mathrm{Am}$ were $0.5 \mathrm{~d}$ and $1.1 \mathrm{~d}$, respectively. ${ }^{75} \mathrm{Se} \mathrm{A}: \mathrm{Y}$ $=100 \times 10^{-0.025 x} ;{ }^{241} \mathrm{Am} \mathrm{A}: \mathrm{y}=100 \times 10^{-0.011 x}, \mathrm{t}_{\mathrm{r} 1 / 2}$ for the slowly exchanging pools (B) were $8.5 \mathrm{~d}$ and $20.2 \mathrm{~d}$ for ${ }^{75} \mathrm{Se}$ and ${ }^{241} \mathrm{Am}$, respectively. ${ }^{75} \mathrm{Se} \mathrm{B}: \mathrm{y}=50.613 \times 10^{-0.00147 \mathrm{~m})}$, $\mathrm{r}^{2}=0.922 ;{ }^{241} \mathrm{Am} \mathrm{B}: \mathrm{y}=78.285 \times 10^{-000062 x}, \mathrm{r}^{2}=0.717$ in the chlorophytes Dunaliella primolecta ( $73 \%$ soluble) and Chlorella sp. (98\% soluble) (Bottino et al. 1984). It appears that many of the seleno-amino acids synthesized by algae cannot be incorporated into protein.

Some phytoplankton species, including Thalassiosira pseudonana, have a biological requirement for selenium (Doucette et al. 1987, Price et al. 1987). The essentiality of this element for marine zooplankton has not been demonstrated. However, the high assimilation efficiency of selenium in marine zooplankton is further evidence that this element enters into the organic cycle, possibly as an analog of sulfur. The dominance of organic selenide compounds (probably seleno-amino acids) among the various selenium species in surface seawater (Cutter \& Bruland 1984) is consistent with this and suggests that this element can be considered as a 'recycled' element (Whitfield \& Turner 1987). The assimilation in biological tissue and organic cycling of selenium probably account for its relatively long residence time $-2.6 \times 10^{4}$ yr (Broecker \& Peng 1982) - in the ocean.

Polonium, another group VIA element, shows comparable behavior to selenium in that it has an almost identical concentration factor in Thalassiosira pseudonana $\left(1.2 \times 10^{5}\right)$ and appears to associate with cytoplasmic protein in phytoplankton (Fisher et al. 1983c). Polonium is also assimilated in crustaceans, primarily in protein in the hepatopancreas (Cherry et al. 1983, Heyraud et al. 1987). ${ }^{210}$ Po consequently enters into the organic cycle in the ocean and shows evidence of being recycled in surface waters, unlike its grandparent ${ }^{210} \mathrm{~Pb}$, which shows comparatively negligible association with organic compounds and negligible recycling behavior in the sea (Bacon et al. 1976, Fisher et al. 1983c, Todd et al. 1986). Americium, which also shows negligible assimilation in marine zooplankton (Fisher et al. 1983b, this report) and which does not appreciably penetrate into the cytoplasm of phytoplankton cells (Fisher et al. 1983c), does not show geochemical evidence that it enters into the organic cycle in the sea and has, like $\mathrm{Pb}$ (Broecker \& Peng 1982), a short residence time in the oceans (Fukai et al. 1979, 1981). Because americium does not assimilate in zooplankton, fecal pellets are enriched with this element relative to the animals that produced them and the food they fed upon (Fisher et al. 1983b, Fowler et al. 1983, this report).

The selenium assimilation efficiency observed here for Acartia tonsa grazing on labeled diatoms ( $97 \%$ ) is higher than that for selenium in euphausiids $(66 \%)$ feeding on Artemia salina that had previously grazed on ${ }^{75} \mathrm{Se}$-labeled phytoplankton (Fowler \& Benayoun 1976). Given the high assimilation efficiency of selenium and reduced accumulation from the dissolved phase, zooplankton probably obtain most of their 
selenium by feeding. Thus, for selenium to be utilized by an animal (or to exert toxic action), it must be associated with particles which are ingested. This is consistent with the observation that only $3 \%$ of the body burden of selenium in the euphausiid Meganyctiphanes norvegica collected in the Mediterranean was associated with the exoskeleton (Fowler 1977).

When determining the assimilation efficiency of an element using a mass balance approach, assessing the quantity of ingested material for short-term experiments involving small animals can be difficult. Collection of excreted material also poses difficulties in that small (80 to $200 \mu \mathrm{m}$ ) fecal pellets are easily lost or broken into smaller fragments during handling. Quantitative loss of material from feces into the dissolved phase poses problems for both mass balance and ratio methods, but can be corrected in the ratio method by knowing the relative loss rates of the assimilated and non-assimilated elements. When using the ratio method, it is important to choose an appropriate inert tracer of ingested material. We found that ${ }^{241} \mathrm{Am}$ is an excellent tracer of bulk food for zooplankton feeding experiments. This transuranic radionuclide is not essential for any organism, but the labeling of food particles with Am is easily accomplished due to its extremely high particle reactivity (Fisher et al. 1983a). Moreover, ${ }^{241} \mathrm{Am}$ is commercially available, has a relatively long half-life (433 yr), and its single, well-defined gamma emission peak at $59.5 \mathrm{keV}$ makes it compatible for use with many other radiotracers, even when using $\mathrm{NaI}(\mathrm{Tl})$ detectors whose resolution is less fine than that of Ge-Li detectors.

Ratio methods for determination of assimilation efficiency have reduced the margin of error in zooplankton feeding experiments to the point where the geochemical implications of such results may be interpreted in an oceanographically consistent way. Whereas gravimetric determinations of carbon assimilation efficiency in Calanus have ranged from 53 to $87 \%$ (Taguchi \& Ishii 1972), assimilation efficiencies based on ratio methodology showed much less variation: $86 \pm 2 \%$ using $C$ and Si tracers (Tande \& Slagstad 1985) and $85 \pm 0.2 \%$, using $C$ and Cr tracers with Acartia tonsa (Reinfelder \& Fisher 1991).

The retention half-time $\left(t_{r 1 / 2}\right)$ of ${ }^{241} \mathrm{Am}$ in the copepod fecal pellets was considerably shorter than that for this isotope in larger euphausiid fecal pellets from the same diet $\left(t_{r 1 / 2}=46 \mathrm{~d}\right)$ (Fisher et al. 1983b), but more than double that of selenium (Fig. 7). Given sinking rates of copepod fecal pellets on the order of 50 to $100 \mathrm{~m} \mathrm{~d}^{-1}$, (Komar et al. 1981), the fecal pellets, which initially have lower selenium concentrations than do the copepods themselves or the food they fed upon, should release essentially all their selenium into the dissolved phase during their descent in the water column.
Acknowledgements. This research was supported by the Water Resources Division, USGS, Menlo Park, California, USA and by NSF Grant OCE 8810657 . We thank G. Lopez and S. Luoma for valuable discussions and S. Dunham for technical assistance.

\section{LITERATURE CITED}

Angel, M. V (1984). Detrital organic fluxes through pelagic ecosystems. In: Fasham, M. J. R. (ed.) Flows of energy and materials in marine ecosystems. Plenum, New York, p. $475-516$

Bacon, M. P., Spencer, D. W., Brewer, P. G. (1976). ${ }^{210} \mathrm{~Pb} /{ }^{226} \mathrm{Ra}$ and ${ }^{210} \mathrm{Po} /{ }^{210} \mathrm{~Pb}$ disequilibria in seawater and suspended particulate matter. Earth Planet. Sci. Lett. 32: 277-296

Bagnall, K. W. (1973). Selenium, tellurium and polonium. In Bailar, J. C., Emeleus, H. J., Nyholm, R., Trotman-Dickenson, A. F. (eds.) Comprehensive inorganic chemistry, Vol. 2. Pergamon Press, Oxford, p. 935-1008

Bottino, N. R., Banks, C. H., Irgolic, K. J., Micks, P., Wheeler, A. E., Zingaro, R. A. (1984). Selenium containing amino acids and proteins in marine algae. Phytochem. 23: $2445-2452$

Bricelj, V. M., Bass, A. E., Lopez, G. R. (1984). Absorption and gut passage time of microalgae in a suspension feeder: an evaluation of the ${ }^{51} \mathrm{Cr}:{ }^{14} \mathrm{C}$ twin tracer technique. Mar Ecol. Prog. Ser 17: 57-63

Broecker, W. S., Peng, T. H. (1982). Tracers in the sea. Eldigio Press, New York

Brown, T. A., Shrift, A. (1982). Selenium: toxicity and tolerance in higher plants. Biol. Rev. 57: 59-84

Calow, P., Fletcher, C. R. (1972). A new radiotracer technique involving ${ }^{14} \mathrm{C}$ and ${ }^{51} \mathrm{Cr}$ for estimating the assimilation efficiencies of aquatic, primary consumers. Oecologia 9: $155-170$

Cherry, R. D., Heyraud, M., Higgo, J. J. W. (1983). Polonium210: its relative enrichment in the hepatopancreas of marine invertebrates. Mar. Ecol. Prog. Ser. 13: 229-236

Conover, R. J. (1966). Assimilation of organic matter by zooplankton. Limnol. Oceanogr. 11: 338-345

Cutter, G. A. (1982). Selenium in reducing waters. Science $217 \cdot 829-831$

Cutter, G. A., Bruland, K. W. (1984). The marine biogeochemistry of selenium: a re-evaluation. Limnol. Oceanogr. 29: $1179-1192$

Doucette, G. J., Price, N. M., Harrison, P. J. (1987). Effects of selenium deficiency on the morphology and ultrastructure of the coastal marine diatom Thalassiosira pseudonana (Bacillariophyceae). J. Phycol. 23: 9-17

Fisher, N. S. (1986). On the reactivity of metals for marine phytoplankton. Limnol. Oceanogr. 31: 443-449

Fisher, N. S., Bjerregaard, P., Fowler, S. W. (1983a). Interactions of marine plankton with transuranic elements. 1. Biokinetics of neptunium, plutonium, americium, and californium in phytoplankton. Limnol. Oceanogr. 28: 432-447

Fisher, N. S., Bjerregaard, P., Fowler, S. W. (1983b). Interactions of marine plankton with transuranic elements. 3. Biokinetics of americium in euphausiids. Mar. Biol. 75: $261-268$

Fisher, N. S., Burns, K. A., Cherry, R. D., Heyraud, M. (1983c). Accumulation and cellular distribution of ${ }^{241} \mathrm{Am},{ }^{210} \mathrm{Po}$, and ${ }^{210} \mathrm{~Pb}$ in two marine algae. Mar. Ecol. Prog. Ser. 11 233-237

Fowler, S. W. (1977). Trace elements in zooplankton particulate products. Nature, Lond. 269: 51-53 
Fowler, S. W., Benayoun, G. (1976). Selenium kinetics in marine zooplankton. Mar. Sci. Communs 2: 43-67

Fowler, S. W., Knauer, G. A. (1986). Role of large particles in the transport of elements and organic compounds through the oceanic water column. Prog. Oceanogr. 16: 147-194

Fowler, S. W., Ballestra, S., LaRosa, J., Fukai, R. (1983). Vertical transport of particulate-associated plutonium and americium in the upper water column of the Northeast Pacific. Deep Sea Res. 30: 1221-1233

Fukai, R., Ballestra, S., Thein, M., Guion, J. (1981). Input of transuranic elements through rivers into the Mediterranean Sea. In: Impacts of radionuclide releases into the marine environment. IAEA, Vienna, p. 3-14

Fukai, R., Holm, E., Ballestra, S. (1979). A note on vertical distribution of plutonium and americium in the Mediterranean Sea. Oceanologica Acta 2: 129-132

Guillard, R. R. L., Ryther, J. H. (1962). Studies of marine planktonic diatoms I. Cyclotella nana Hustedt, and Detonula confervacea (Cleve) Gran. Can. J. Microbiol. 8: 229-239

Heyraud, M., Cherry, R. D., Dowdle, E. B. (1987). The subcellular localization of natural ${ }^{210} \mathrm{Po}$ in the hepatopancreas of the rock lobster (Jasus lalandii). J. environ. Radioact. 5: 249-260

Komar, P. D., Morse, A. P., Small, L. F., Fowler, S. W. (1981). An analysis of sinking rates of natural copepod and euphausid fecal pellets. Limnol. Oceanogr. 26: 172-180

Measures, C. I., Burton, J. D. (1980). The vertical distribution and oxidation states of dissolved selenium in the northeast Atlantic Ocean and their relationship to biological processes. Earth Planet. Sci. Lett. 46: 385-396

Price, N. M., Thompson, P. A., Harrison, P. J. (1987) Selenium: an essential element for growth of the coastal marine diatom Thalassiosira pseudonana (Bacillariophyceae). J. Phycol. 23: 1-9

This article was submitted to the editor
Reinfelder, J. R., Fisher, N. S. (1991). The assimilation of elements ingested by copepods. Science (in press)

Shrift, A. (1954). Sulfur-selenium antagonism. I. Anti-metabolite action of selenate on the growth of Chlorella vulgaris. Am. J. Bot. 41: 223-230

Small, L. F., Knauer, G. A., Tuel, M. D. (1987). The role of sinking fecal pellets in stratified euphotic zones. Deep Sea Res. 34: 1705-1712

Smith, P. K., Krohn, R. I., Hermanson, G. T., Mallia, A. K., Gartner, F. H., Provenzano, M. D., Fujimoto, E. K., Goeke, N. M., Olson, B. J., Klenk, D. C. (1985). Measurement of protein using bicinchoninic acid. Analyt. Biochem. 150: $76-85$

Taguchi, S., Ishii, H. (1972). Shipboard experiments on respiration, excretion, and grazing of Calanus cristatus and $C$. plumchrus (Copepoda) in the northern North Pacific. In: Takenouti, A. Y. (ed.) Biological oceanography of the northern North Pacific Ocean. Idemitsu Shoten, Tokyo, p. $419-431$

Tande, K. S., Slagstad, D. (1985). Assimilation efficiency in herbivorous aquatic organisms - The potential of the ratio method using ${ }^{14} \mathrm{C}$ and biogenic silica as markers. Limnol. Oceanogr. 30: 1093-1099

Todd, J. F., Wong, G. T. F., Reid, D. F. (1986). The geochemistries of ${ }^{210} \mathrm{Po}$ and ${ }^{210} \mathrm{~Pb}$ in waters overlying and within the Orca Basin, Gulf of Mexico. Deep Sea Res. 33: 1293-1306

Turner, J. T. (1977). Sinking rates of fecal pellets from the marine copepod Pontella meadii. Mar. Biol. 40: 249-259

Whitfield, M., Turner, D. R. (1987). The role of particles in regulating the composition of seawater. In: Stumm, W. (ed.) Aquatic surface chemistry: chemical processes at the particle-water interface. Wiley, New York, p. 457-493

Wrench, J. J. (1978). Selenium metabolism in the marine phytoplankters Tetraselmis tetrathele and Dunaliella minuta. Mar. Biol. 49: 231-236

Manuscript first received: July 25, 1990

Revised version accepted: December 11, 1990 